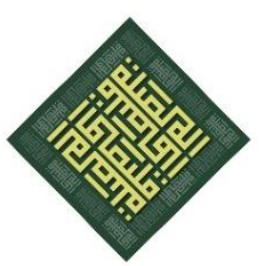

El-Mashlahah

Volume 11 No. 2, December 2021

ISSN: E-ISSN: 2622-8645; P-ISSN: 2089-1970

DOI: $10.23971 /$ elma.v11i2.3181

\title{
THE RELEVANCE OF THE THEORY OF LEGAL CHANGE ACCORDING TO IBNU QAYYIM AL-JAUZIYYAH IN LEGAL PRODUCTS BY FATWA DSN-MUI INDONESIA
}

\author{
Muhamad Izazi Nurjaman, Doli Witro \\ Faculty of Sharia and Law, UIN Sunan Gunung Djati Bandung, Indonesia \\ doliwitro01@gmail.com
}

Received: 17-08-2021; Accepted: 15-11-2021; Published: 23-12-2021;

\begin{abstract}
The study described the relevance of the theory of legal change according to Ibnu Qayyim al-Jauziyyah to the legal product of the fatwa DSN-MUI (Fatwa National Sharia Board-Indonesian Council of Ulama) in Indonesia. It used a qualitative research method with a literary approach. The conclusions showed that the relevance of the theory of legal change proposed by Ibn Qayyim al-Jauziyyah has been applied explicitly in every legal product of the fatwa DSN-MUI in Indonesia. That seen in every legal product, always give the way for future changes following the needs and problems faced. Changes to Islamic legislation products have significant differences. On laws and regulations and judges' decisions, new legal products will cancel or revoke the previous legal. And, for the legal product of a fatwa from the National Syari'ah Board (DSNMUI), the newly legal product will complete the previous one. However, legal changes will always occur in the context of providing legal certainty, accompanied by the level of benefit for people's lives.
\end{abstract}

Keywords: Legal Changes; Ibn Qayyim; and Products of Islamic Law;

\section{ABSTRAK}

Penelitian ini menjelaskan tentang relevansi teori perubahan hukum menurut Ibnu Qayyim al-Jauziyyah terhadap produk hukum fatwa DSN-MUI di Indonesia. Artikel ini menggunakan metode penelitian kualitatif yang bersifat kepustakaan. Hasil penelitian menunjukkan bahwa relevansi teori perubahan hukum yang digaungkan oleh Ibnu Qayyim al-Jauziyyah sudah diberlakukan secara eksplisit dalam setiap produk hukum fatwa DSN-MUI di Indonesia. Hal itu dapat dilihat dalam setiap batang tubuh produk hukum yang selalu membuka jalan untuk adanya perubahan dikemudian hari sesuai dengan kebutuhan dan problematika yang dihadapi. Perubahan terhadap produk hukum Islam memiliki perbedaan yang signifikan. Bagi peraturan perundang-undangan dan putusan hakim, ketentuan hukum baru akan membatalkan/mencabut ketentuan hukum sebelumnya. Sedangkan terhadap ketentuan hukum berupa fatwa Dewan Syari'ah Nasional (DSN-MUI), ketentuan hukum baru akan menyempurnakan ketentuan hukum sebelumnya. Namun sejatinya perubahan hukum akan selalu terjadi dalam rangka menciptakan produk hukum yang dapat memberikan kepastian hukum disertai pencapaian tingkat kemaslahatan bagi kehidupan masyarakat.

Kata Kunci: Perubahan Hukum; Ibnu Qayyim; dan Produk Hukum Islam; 


\section{Introduction}

Not all Islamic law or sharia is clearly and explicitly stated in the Al-Quran and Hadith. ${ }^{1}$ In addition, not every person can easily understand the laws mentioned in the Al-Quran and Hadith. ${ }^{2}$ A certain problem requires the ijtihäd of the scholars. Besides that, the law has a position in society, not only as a medium to keep the orderly (rule), but also has a role as a medium to change the mindset and behavior of people in daily lives. ${ }^{3}$ The experts said that the legal position is dynamic, not static, and must show the role in protecting the community. Therefore, the law must stand firmly as a driver, or even a pioneer, aiming to advance the lives of people to be better and benefits for all parties. $^{4}$

The law will always relate to the process of its formation. The formation of law is inseparable from the position and criteria of the community. Traditional and modern societies have a different processes of forming values and legal norms. Where in traditional societies, the formation of law is conducted as part to reflect the values and norms agreed upon and live among them. In contrast, the law formation in modern society must through a process of power struggle because of the difficulty of agreeing on a value and norm due to the position of a more advanced society. Here, it requires the role of the state, as a neutral power, to resolve conflicts without taking sides with each other. ${ }^{5}$

The life of society, with increasingly complex, always goes hand in hand with the problems it faces. If the legal position is static, then, the legal position is not possible to answer various problems of people. In this case, the law cannot work in dealing with the existing problems. Because, the truth of the people to law is that, how the law can achieve its goals to the maximum level of community satisfaction in fulfilling their expectations.

When the law is inseparable from the social life of the communities, then it may influence the legal position. In this example, the life of the community becomes one of

\footnotetext{
${ }^{1}$ Sarpini, "Prosedur Menyelesaikan Kasus Hukum Dengan Ijma'," El-Mashlahah 9, no. 1 (2019): 16-28, https://doi.org/https://doi.org/10.23971/el-mas.v9i1.1256.

2 Ibnu Elmi A.S Pelu, "Kedudukan Fatwa DAlam Konstruksi Hukum Islam," El-Mashlahah 9, no. 2 (2019): 167-81, http://e-journal.iain-palangkaraya.ac.id/index.php/maslahah/article/view/1294.

${ }^{3}$ Marwan Mas, Pengantar Ilmu Hukum (Bogor: Ghalia Indonesia, 2015).

${ }^{4}$ Abdul Manan, Aspek-Aspek Pengubah Hukum (Jakarta: Prenamedia Group, 2018).

${ }^{5}$ Ishaq, Dasar-Dasar Ilmu Hukum (Jakarta: Sinar Grafika, 2018).
} 
the factors in determining the change of the legal position. On the one hand, social change must always follow legal values and norms. However, there is a possibility that legal values and norms must adapt to social changes. ${ }^{6}$

But, the general statement is that people's lives will always change among the life of political, economic, social, and cultural. So, the legal values and norms will always change following the changes in the life of people. As in Islamic law, Prophet Muhammad PBUH said, "every hundred years (one century), there will be someone who will renew the understanding of religion." This statement proves that Islamic law has a harakah character, which defines Islamic law as always moving and developing dynamically through self-formulating against the times. ${ }^{7}$

On one hand, the main concern is, whether the ever-changing Islamic law affects the position of the source of the law? Then, Ibn Qayyim answered, by dividing Islamic law based on its characteristics. First, Islamic law has a characteristic of permanent static. Second, Islamic law has a characteristic of dynamic. ${ }^{8}$ The Islamic law of permanent static characteristics will not change from its original position. For example, the law regarding aqiidah (faith), worship, and morals, which cannot be renewed even though occur a change in time and place, and the path of ijtihäd is closed. Meanwhile, the Islamic law of dynamic characteristic has a chance to change following the changes in benefit, time, and place, such as mu'ämalah term. Thus, mu'ämalah opens the path of ijtihăd, thereby opening up legal changes in Islamic law.

Besides dividing Islamic law, related to ijtihād in terms of mu'ämalah, which will open legal changes. Ibn Qayyim established a theory of legal change, namely the changes and differences in fatwa caused by the changes in times, places, situations and conditions, intentions, and customs. Haris Muslim stated this concept has proven the universality and flexibility of the position of Islamic law as a legal provision, that is adaptable to time, place, situation, and condition. So, through this characteristic, the law

\footnotetext{
${ }^{6}$ Samsir Salam, "Hukum Dan Perubahan Sosial (Kajian Sosiologi Hukum)," Tahkim: Jurnal Hukum Dan Syariah 11, no. 101 (2015): https://jurnal.iainambon.ac.id/index.php/THK/article/view/12.

${ }^{7}$ Alaudin Koto, Filsafat Hukum Islam (Jakarta: RajaGrafindo Persada, 2014).

${ }^{8}$ Ma'ruf Amin, Fatwa Dalam Sistem Hukum Islam (Jakarta: eLSAS, 2011).

https://e-journal.iain-palangkaraya.ac.id/index.php/maslahah/index
} 
can deal with every existing problem. And, it stands firmly and strongly in answers to all problems of life. ${ }^{9}$

Islamic law has an equal position with customary law and western law. In the past years, the implementation of Islamic law had to be legitimized by customary law. Islamic law is not possible to be applied when the implementation is not following the customary law. However, along way, Islamic law can stand alone and be a source of law in national law, as well as other sources of law. Islamic law had already been implemented into various legal products in the management of national law, including legislation, judges' decisions, and the conclusion of fatwas by the DSN-MUI.

Studies on the thoughts of Ibn Qayyim al-Jauziyyah have been carried out by previous scholars. Basri Rusdaya discussed the thoughts of Ibn Qayyim al-Jawziyyah on the effects of social change. ${ }^{10}$ Samsir Salam wrote the relationship between law and social change seen from the study of the sociology of law. ${ }^{11}$ Rahmawati wrote the paradigm of Islamic law changing. It explores the context of Ibn Qayyim al-Jauziyah's thoughts. ${ }^{12}$ Then, Abdi Wijaya discussed the law changes in Ibn Qayyim's thoughts. Furthermore, Haris Muslim discussed the thoughts of Ibn Qayyim al-Jauziyyah on the changes in fatwas and their relevance to the implementation of Islamic law in Indonesia. The previous articles have similarities and differences with this article. First, it discusses the thought of Ibn Qayyim and legal changes. Second, the difference is in its relevance in viewing the current Indonesian context, especially the fatwa issued by the National Sharia Board-Indonesian Council of Ulama (DSN-MUI).

The main problem is, whether the theory of legal change according to Ibn Qayyim, which is applied in the fiqh rules, can be applied in the Islamic law in Indonesia? To find out the answer, it needs to analyze the relevance of the theory of legal change according to Ibnu Qayyim to the position of the DSN-MUI fatwa legal

\footnotetext{
${ }^{9}$ Haris Muslim, "Pemikiran Ibnu Qayyim Al-Jauziyah (W 751 H/1350 M) Tentang Perubahan Fatwa Dan Relevansinya Dengan Penerapan Hukum Islam Di Indonesia," Al-Mashlahah Jurnal Hukum Islam Dan Pranata Sosial Islam 8, no. 2 (2020): 285-313, http://jurnal.staialhidayahbogor.ac.id/index.php/am/article/view/809.

${ }^{10}$ Rusdaya Basri, "Ibnu Qayyim Al-Jawziyyah Tentang Pengaruh Perubahan Sosial," Al-Manahij: Jurnal Kajian Hukum Islam, 2015, https://doi.org/10.24090/mnh.v9i2.489.

${ }^{11}$ Salam, "Hukum Dan Perubahan Sosial (Kajian Sosiologi Hukum)."

12 Rahmawati, "Paradigma Perubahan Hukum Islam (Eksplorasi Pemikiran Ibnu Qayyim AlJauziyah)," Al-Bayyinah 1, no. 2 (2017): 17-28, https://doi.org/https://doi.org/10.35673/albayyinah.v1i2.14.
} 
product in Indonesia. With that, the article will provide a comprehensive picture of the application of the theory. And, the particular article aimed to find out the relevance of the theory of legal change according to Ibn Qayyim al-Jauziyyah to the legal product of the fatwa DSN-MUI in Indonesia.

\section{Method}

The article tried to describe how Islamic law can be a means of social engineering, especially its position as a source of law in Indonesia. For this reason, the article used a qualitative descriptive research method with a literature study approach. In legal research, it is called normative legal research. ${ }^{13}$ The data were obtained through a searching process, then filtered and analyzed to produce a descriptive series to be presented in this article. The data sources obtained from reference materials, including books, titles, and others sources that have been through the process of review following the focus of the discussion in this article.

\section{Findings and Discussion}

\section{Application of Law as A Tool of Social Engineering Rescoe Pound}

In legal science literature, the general concept of Law as a Tool of Social Engineering was first stated by Roscoe Pound, an American legal expert of the Sociological Jurisprudence. Sociological Jurisprudence is a school of legal philosophy developed by Eugen Erlich in Europe, and by Roscoe Pound in America. ${ }^{14}$ This school emphasizes the law that is seen not only on normative but also both normative and sociological phenomena at the same time. According to experts, this approach is a middle ground between two approaches, historical and positivism. The historical approach of thought views the law as sociological, and the positivism approach views the law as legal only. ${ }^{15}$

${ }^{13}$ Sabarudin Ahmad, Novita Anggraeni, and Andrian Kukuh Pambudi, “A. Djazuli’s Thinking Regarding Hifzu Al-Ummah: Dismissing the Entangled Bureaucracy to Commemorate the Era of Society 5.0," Journal de Jure 12, no. 1 (2020): 86-101, https://doi.org/10.18860/j-fsh.v12i1.8700.

${ }^{14}$ Lili Rasyidi and Rasyidi Ira, Dasar-Dasar Filsafat Hukum (Bandung: Citra Aditya, 1990).

15 Rasyidi and Ira. In the historical approach, the law grows and develops together with the community. Then, the law is not created by the authorities, but grows and develops following the development of society. In other words, the law is a product of society. Therefore, the view of this school of history is called sociological. In contrast, with a positivistic approach, the law is the sole command of the government. On the one hand, it makes the role of the government in the creation of law is very dominant. Moreover, it can be argued that in legal positivism, the development of law is in the hands of the government. Thus, if the law is merely an order from the government, this can lead to the direction and development of the law for the future which can be planned according to the needs of the 
Legal experts generally distinguish between Sociological jurisprudence and the sociology of law, although they both study law about society. In the scientific family, Sociological Jurisprudence is a branch of the philosophy of law, while the sociology of law is a branch of sociology. ${ }^{16}$ In terms of the object of study, they are also different. Sociological Jurisprudence uses a legal approach to society while the sociology of law is from society to law. ${ }^{17}$ Substantially, they have significant differences. If sociological jurisprudence focuses on law and views society about law, the sociology of law seeks to create a science of social life as a whole and its discussion covers the largest part of both sociology in general and political science. The emphasis of the investigation is on society and law as a manifestation. ${ }^{18}$

Discussing Rescoue Pound with the concept of law as a tool of social engineering means discussing the context of the legal function in society. As a follower of sociological jurisprudence, according to Rescoue Pound, the law must be viewed in terms of its function, which has function as a tool to manipulate (change) society. As a tool of social engineering, the function of law is not only to reach and keep longer the power but also plays as a tool to make changes in the middle of society. ${ }^{19}$ The goal is, to aim society to the expected goal. Furthermore, the law may use as a means to eliminate various bad habits of society, to become better habits. ${ }^{20}$

Related to this function, several types of interests must be protected by the law. First, public interest. It includes the interests of the state as a legal entity and guardian of the public interest. Second, the Social Interest. It includes the interests of peace and order, protection of social institutions, prevention of moral decline, prevention of

government. In such a legal understanding, it can be understood that the element of legal certainty is the most prominent in legal positivism. Hotma P Sibuea and Waty Suwarty Haryono, "Pengaruh Mazhab Hukum Sosiological Jurisprudence Terhadap Perkembangan Pembangunan Hukum Di Indonesia Pada Masa Orde Baru," Jurnal Filsafat Hukum 1, no. 1 (2015): 103-11, http://journal.uta45jakarta.ac.id/index.php/JFH/article/view/1480.

${ }^{16}$ Rasyidi and Ira, Dasar-Dasar Filsafat Hukum.

${ }^{17}$ Rasyidi, Filsafat Hukum.

18 Dardi Darmodiharjo, Pokok-Pokok Filsafat Hukum: Apa Dan Bagaimana Filsafat Hukum Indonesia (Jakarta: Gramedia Pustaka Utama, 1996).

${ }^{19}$ Rasyidi and Ira, Dasar-Dasar Filsafat Hukum.

${ }^{20}$ Satjipto Raharjo, Ilmu Hukum (Bandung: Alumni, 1986). 
violations of rights, and social welfare. Third, private interests. It includes individual interests, family interests, and property rights. ${ }^{21}$

According to A.P, Edi Atmaja, the word "tool" in the concept is not interpreted literally. But, it is interpreted as a means because the law is closely related to community factors, including beliefs, faith, and culture. The notion of 'tool' with a tool will make a rigid legal definition, thus ignoring its sociological aspects. There are proposed assumptions associated with this definition. First, the law contains doctrinal sources, such as values and principles, so that it provides content and substance in the development of law. Second, the law will always be dynamic, and will naturally develop along with the development of society. Third, the developments of legal will run regularly in a system to deal with human needs. Fourth, the function of the law is to regulate and keep the process of legal development can run freely (freedom). ${ }^{22}$ Thus, it concluded that the law in Rescoe Pound's view can be used as a means to make changes in the society so that arises a rule to change a negative habit into a positive habit, as a response to social and cultural changes of the community itself.

In Roscoue's view, the law is used as a tool to make changes in society that must occur in an orderly and planned. In this theory by Rescoue Pound, the dominant role of the state cannot be avoided. However, in this context, Pound's rescoue lives in an American country that adheres to a common law legal system, in which the making of laws is not in the hands of the legislature (law-making institutions) different from countries that follow the civil law legal system. In the common law system, the creation of law is in the hands of the judges, which are legally written in a judicial decision, which is the Supreme Court. ${ }^{23}$ Thus, the theory is relevant when applied in a state that adheres to the common law legal system. But, it might not be relevant to be applied to a civil law state legal system, such as Indonesia.

Mochhtar Kusumaatmaja in Soetandyo realized this problem when he introduced the sociological jurisprudence theory with the concept of Rescoue Pound, and applied

${ }^{21}$ Johannes Ibrahim Kosasih and Yohanes Hermanto Sirait, "Konsepsi Law As A Tool Of SOcial Engineering Sebagai Upaya Manajemen Hukum Dalam Menciptakan Kepastian Hukum," in Konferensi Nasional Optimalisasi COmminity Well-Being Dalam Perspektif Multidisipliner (Bandung: Fakultas Psikologi Universitas Kristen Maranatha, 2015), 45-46.

${ }_{22}$ A.P. Edi Atmajaya, "Hukum Sebagai Sarana Rekayasa Sosial," Opini Radar Lampung, 2012, https://issuu.com/ayep2/docs/300512/6.

23 Sibuea and Haryono, "Pengaruh Mazhab Hukum Sosiological Jurisprudence Terhadap Perkembangan Pembangunan Hukum Di Indonesia Pada Masa Orde Baru.” 
the theory in Indonesia with the emergence of the theory of development law. In this theory, the law is not only played as a tool, but also a means of community renewal. In an article, Mochtar Kusumaatmaja once stated, that maximizing the law as a means of community renewal to reach government policies to develop the country is assumed to be more urgent than developed countries with already have a legal system that works to accommodate the changes occurring in the middle of society. While developing countries do not have such a legal system. ${ }^{24}$ Also, Mokhtar Kusumaatnaja stated that national development is intended to develop all aspects of people's lives. Community development can be characterized by the changes that occur. And, the role of law during development is, to assure that the changes occur orderly and regularly. ${ }^{25}$

Then, the problem is, how the concept of law as a tool of social engineering, which is practiced with the common law legal system, to be applied in countries with having a different legal system. For this reason, Mokhtar Kusumaatmaja explained in his statements. He stated that DPR (The House of Representatives of the Republic of Indonesia), as the people's representative in the process of forming laws following Article 11 of the Constitution, is the institution that can express legal awareness that lives in society. ${ }^{26} \mathrm{He}$ further stated that, besides the people's representative institutions, public legal awareness may arise through legal research conducted by educational and research institutions, as well as individuals. The role of the judiciary (judges), according to Mochtar Kusumaatmaja, also plays a role in the formulation of laws. He stated that jurisprudence is an important source of legal identification in society, added by the opinions of legal experts and scholars, especially those who are prominent in a particular branch of law science. ${ }^{27}$

There are two reasons, Hotma P Sibuea argued why DPR is the most appropriate state institution to grow up the legal awareness or values that live in society. First, the DPR is a state institution whose members are people's representatives who are elected in a general election. Therefore, a people's representative who sits in the DPR must know exactly the aspirations and interests of the constituents who choose them. Here,

${ }^{24}$ Soetandyo Wigisoebroto, Dari Hukum Kolonial Ke Hukum Nasional: Dinamika Sosial Politik Dan Perkembangan Hukum Di Indonesia (Jakarta: Rajawali Press, 1994). 2002).

${ }^{25}$ Mochtar Kusumaatmadja, Konsep-Konsep Hukum Dalam Pembangunan (Bandung: Alumni,

${ }^{26}$ Kusumaatmadja.

${ }^{27}$ Kusumaatmadja.

https://e-journal.iain-palangkaraya.ac.id/index.php/maslahah/index 
hypothetically, a member of DPR is expected to know and be sensitive to the people's aspirations. Second, according to the Indonesian constitutional system, the DPR constitutionally is a state institution authorized to make laws. ${ }^{28}$

Thus, in practice, the legal reform process in Indonesia is dominated by legislation. This fact shows, that in Indonesia, the effort to implement social reform with the law as a tool is a manifestation of legal positivism which emphasizes the reform through the law (written law).

In its development, Mochtar Kusumaatmaja with the theory of development law is assumed as failed in the efforts towards the idealization of a prosperous Indonesian state by using law as a means of social reconstruction. The fail is because the law formed by the DPR is not a law that contains elements of certainty and justice, as well as conceptualized by the sociological jurisprudence school. At that time, the law that was formed by the DPR more emphasized the element of certainty, while the aspect of justice was not always manifested proportionally (balanced). In a theory of legal function, the law formed by DPR during the New Order era emphasized its instrumental function than its expression function. The reason, the law during the New Order period served more as a tool to realize the programs determined by the authorities rather than realizing the aspirations and interests of the people. The program that has been determined by the government is like an employer who must be served and served by the law well, even though the interests of the people are not served and neglected. Moreover, the political and economic position of the lower-class of society is very weak that they do not have a strong political position to impose their aspirations and interests to be accommodated by the DPR into laws or other government legal products. ${ }^{29}$

\section{Formalization of Islamic Law as Social Engineering in Indonesia}

The sentences of Islamic law are not found in the sources of Islamic teachings and classical Islamic literature. Most mentioned are the terms of Islamic sharia, sharia law, fiqh, and sharia. ${ }^{30}$ The term Islamic law is often mentioned by orientalists with the sentence of Islamic Law, which literally translated into Indonesian is hukum Islam or

28 Sibuea and Haryono, "Pengaruh Mazhab Hukum Sosiological Jurisprudence Terhadap Perkembangan Pembangunan Hukum Di Indonesia Pada Masa Orde Baru.”

${ }^{29}$ Sibuea and Haryono. 1993).

${ }^{30}$ Amir Syarifuddin, Pembaharuan Pemikiran Dalam Hukum Islam (Padang: Angkasa Raya, 
Islamic law. ${ }^{31}$ When it is associated with the terms shari'a and fiqh, then Islamic law covers both terms because Islamic law is essentially a law based on Allah's revelation. ${ }^{32}$

According to Hasbi Ash-Shiddieqy, Islamic law is the manifestation of fiqh alIslam and shari'a al-Islam. Based on the terminology of Islamic law, according to Hasbi, there is a distinction beitween fiqh Islam and sharia Islam. Hasbi argued that Islamic law is a collection of the efforts of the fuqaha in implementing the sharia Islam according to the needs of the community. ${ }^{33}$ Thus, sharia Islam is the domain of Allah's revelation, while fiqh Islam is a product of reason which is a form of revelation implementation from the two main sources of Islamic law, namely the Qur'an and hadith that based on the benefit of human life. Aspects of the Shari'a usually regulate principled human behavior, so the benefits lie in the specific and general rules that have been outlined by the sharia. Therefore, the legal provisions are usually static and rigid. On the other hand, in fiqh, the dimensions of benefit are regulated in general, and the application of which cannot be separated from the development of the dynamics of human social and cultural life itself. Therefore, the law in the fiqh, in general, will always change.

Islamic law is a norm that always lives following the dynamics of society, having a constant movement and always develop. Thus, Islamic law will always grow and develop itself is the nature of Islamic law, having a character and specific characteristics, namely intact, harmonious and dynamic. Islamic law always moves in the circle of the benefit of human life. ${ }^{34}$ Through this explanation, Islamic law has an inseparable functional relationship with society as Islamic law regulates human behavior and actions as its object (mahkum fih).

A challenge for Islamic law to be responsive is the rapid dynamics of the development of human life, including social, cultural, political, legal, and others. The changes in human life have positive values for human life, but not a few also bring negative values to human life, even though the purpose of Islamic law is to maintain human life which can simply be formulated to maintain benefit and eliminate the harm

31 Ahmad Hasan Ridwan and Irfan Safruddin, Dasar-Dasar Epistemologi Islam (Bandung: Pustaka Setia, 2011).

${ }^{32}$ Syarifuddin, Pembaharuan Pemikiran Dalam Hukum Islam.

${ }^{33}$ M. Hasbi Ash-Shiddieqy, Filsafat Hukum Islam (Jakarta: Bulan Bintang, 1975).

${ }^{34}$ Ridwan and Safruddin, Dasar-Dasar Epistemologi Islam. 
or disadvantages to life. For this reason, how does Islamic law respond to it? while the texts as sources of Islamic law are quantitatively limited, as well as fiqh products in fiqh literature which are the result of past intellectual property riches by socio-cultural settings of the people at that time. This is where the role of ijtihäd with the function of actualization and re-actualization finds could work.

Concerning society, Islamic law comes in two forms. First, legalizing the norms that are impersonally formed by the community. And, intervening in these norms, including eradicating a tradition in society that is not following the Sharia such as the prohibition of khamr (liquor/wine), and guiding people to behave following the Sharia. ${ }^{35}$ In this context, Islamic law, like any other law, can be used as a means of social engineering. In line with the principles of Islamic teachings which are also one of the principles of Islamic law, are the principle of Enjoining what is right (amr al-ma'ruf) and forbidding what is wrong (nahy al-munkar). According to A. Halil Thahir, the command to goodness (amr al-ma'ruf) is a form of social engineering of Islamic law, namely realizing a better and dignified human life as it is natural with methods and approaches that can be accepted by common sense, traditions, and culture of society. Whereas the meaning of nahy al-munkar of Islamic law means social control, ${ }^{36}$ which plays as a ruler of human life so that life depend on benefits and avoids mudarat (harm or disadvantages). ${ }^{37}$

Discussing social engineering, Islamic law serves as a means of change in society and leads to real social changes in society. This task is manifested in the effort of strengthening the habit patterns in society, leading them to the desired goals, eliminating unnecessary habits, and creating new habit patterns. ${ }^{38}$

In many ways, when Islamic law becomes part of a Muslim's religion, it will often be faced with traditions that already exist and are rooted in the culture of society. Then, there will occur a dialectic between the practice of Islamic law which is part of Islam, and the cultural practices of the community. With Islam, it is not true that all of already

35 This case here is like Islam which regulates the practice of polygamy which has become a culture of Arab people for a long time without paying attention to women. Islam regulates polygamy by bringing moral ideas into it.

36 A. Halil Thahir, Ijtihad Maqashid: Rekonstruksi Hukum Islam Berbasis Interkoneksitas Maslahah (Yogyakarta: LKiS Pelangi Aksara, 2015).

${ }^{37}$ Izomiddin, Pemikiran Dan Filsafat Hukum Islam (Jakarta: Prenamedia Group, 2018).

${ }^{38}$ Soerjono Soekanto, Pemikiran Sosiologi Terhadap Hukum (Jakarta: Bina Aksara, 1998). 
a continuous habit becomes forbidden. When looking at the fiqh literature, often stated that Islam is very appreciative either to the traditions or habits of good society and in line with the benefit of human life itself. We all can see a legal rule ${ }^{39}$ that reads العادة is the reason for a good community tradition also a part of Islamic law itself, especially in mu'āmalah matters. But, a tradition must meet several criteria to become a law. First, a tradition must not conflict with a strict text. Second, a behavior that becomes a custom or tradition must continue to apply and develop in the middle of the community. Third, tradition is common because common laws cannot be determined by a specific tradition. $^{40}$

An example is, harta parpantangan (prenuptial property) which departs from the culture of the Banjarese community. Harta parpantangan is defined as joint property in marriage, or Javanese terms, called harta gono gini (has the same as meaning as Harta Parpantangan). As in Banjarese culture, a wife is usually considered to help her husband in married life, both working outside the home and in sharing tasks, namely, the husband works outside the home and the wife works as a housewife. Activities during the status of husband and wife are considered as a form of cooperation. Therefore, the acquired property while they are in the same household (husband and wife) are approved as joint property. Appreciating the wife's role in the household as a form of cooperation with the husband is a bilateral community culture. This status is different from the Arab culture in general, which is dominantly patriarchal, considers that the husband's property who works outside the home is the husband's property, not the wife's property. ${ }^{41}$ The concept of harta parpantangan ${ }^{42}$ is the result of ijtihād conducted by Sheikh Arsyad Al-Banjari concerning inheritance provision. It is a manifestation of the dialectic of Islamic law which respects the role of husband and wife in the household with community customs that have long-lived as a living law system in

${ }^{39}$ The rule in Islamic law becomes a foundation in establishing a law and many cases of law in which refer to the rules. From this foundation of rule, arise a fiqh rule. This shows that scholars, in the past time, have a big concern for the tradition and custom that life and develop in the middle of the community. The majority of scholars define the word "al-Adat" and 'Urf' as different, but, the meaning and definition of both words are referred to a tradition and habit that is continuous life and well-known by the community itself. DAR NELA PUTRI, "Konsep Urf Sebagai Sumber Hukum Dalam Islam," ElMashlahah 10, no. 2 (2020): 14-25, https://doi.org/10.23971/maslahah.v10i2.1911.

${ }^{40}$ Ash-Shiddieqy, Filsafat Hukum Islam.

${ }^{41}$ Ahmadi Hasan, Adat Badamai (Banjarmasin: Antasari Press, 2007).

${ }^{42}$ M. Fahmi Al-Amruzi, Harta Kekayaan Perkawinan Studi Komparatif Fiqh, KHI, Hukum Adat Dan KUHPerdata (Yogyakarta: Aswaja Pressindo, 2013).

https://e-journal.iain-palangkaraya.ac.id/index.php/maslahah/index 
society. These practices gain legitimacy in Islamic law, and in the end, become an integral part of the application of Islamic law itself, especially in Indonesia.

Islamic law in Indonesia, theoretically and factually, is one of the laws that exist and grow in the middle of society, which is predominantly Muslim. Denying the existence of Islamic law in Indonesia is the same as denying the existence of Muslims themselves as an integral part of the Indonesian people. Therefore, Islamic law is recognized as one of the sources of national law which have been expressly stated in the 1999 GBHN in the reform era. ${ }^{43}$ This means, in making legislation, Islamic law takes part as a legal material for the product of national legislation.

Islamic law may be understood from two views, science and a product of science. Islamic law, in the context of science, is the scientific characteristics of the Islamic law that are produced through the accumulation of knowledge that is structured through certain principles. The knowledge is centered in a unified system and has certain methods. ${ }^{44}$ As a product of science, Islamic law has four kinds of products, namely figh books, the fatwa of ulama, court decisions, and law. ${ }^{45}$ In the context of Indonesia which applies juridical positivism, ${ }^{4647}$ to realize the Islamic law as a tool of social engineering must make the Islamic law a product of official legislation. Without entering into the positive realm, Islamic law will only become a product of fiqh which is ideological and teaching for its followers. ${ }^{48}$

43 A. Qadri Azizi, Eklektisme Hukum Nasional: Kompetisi Antara Hukum Islam Dan Hukum Umum (Yogyakarta: Gema Media, 2002).

${ }^{44}$ Yusdani, Menuju Hukum Keluarga Progresif (Jakarta: Kaukaba, 2015).

45 Yusdani.

${ }^{46}$ Juridical positivism is a school in legal philosophy that adheres to the notion, that only what is approved to be reality can be accepted as truth and right. Positivism as a philosophical school emerged in the 19th century with its figures including Auguste Comte (1779-1854 AD) and Herbert Spencer (18201903). Meanwhile, Juridical Positivism was pioneered by the legal school of Humanism, whose the figure is Jean Bodin with his theory of the sovereignty of the King. Theo Hujbers, Filsafat Hukum Dalam Lintasan Sejarah (Yogyakarta: Kanisius, 1982).

47 In Indonesia, all forms of law will be effective when they have been promulgated by the authorities (government of the Republic of Indonesia). On the other hand, no matter how good and complete the existing legal regulations in Indonesia are, they will not apply if they have not been officially promulgated by the authorities. Mujar Ibnu Syarif, Ide Taqnin Ibn Al-Muqaffa Dan Relevansinya Dengan Penerapan Syariat Islam Di Indonesia (Jakarta: Renaisan dan Formasi, 2005).

${ }^{48}$ In the history of Islamic legal thought, making the positive of Islamic law into legislation is known as taqnin, which was first coined by Ibn al-Muqaffa in a letter that sent to Caliph Ja'far al-Mansur of the Abbasid dynasty. The letter is called Risalah al-Shabah. In the developing years of this thought, the scholars were divided into two groups, first the group that allowed taqnin al-Ahkam with various arguments. And second, the group of scholars that do not justify taqnin al-Ahkam with various arguments. The difference is the issue of the position of judges who must conduct ijtihad and the reality of diversity 
By this discussion, the discourse on the formalization of Islamic law in Indonesia is inevitable because the goal is to make Islamic law an official (positive) law and applicable in Indonesia. This discussion has been going on for a long time, from the colonial era until today. In a relationship between Islamic law and the state, at least, three paradigms have developed related to the formalization of Islamic law. First, a unified paradigm. This paradigm views the state with two functions, religious and political institution. As the impact, the head of state is the holder of religious and political power. The government is based on the sovereignty of God. Thus, the laws that are implemented in the state system are the laws of God (sharia).

From an integral perspective, the enforcement and application of Islamic law as positive state law is a necessity. ${ }^{49}$ The second, the symbiotic paradigm. This paradigm views religion and state as having a symbiotic relationship. Religion needs the state because, through the state authority, religion can always develop and live. Also, the state needs religion due to the process of developing the state needs the guidance of spiritual ethics and morals.

This paradigm comes from al-Mawardi's theory, that state leadership is an instrument to continue the prophetic mission in maintaining religion and regulating world life. In this case, maintaining the religion and the state are two different types of activities but have a prophetic mission relationship. In this concept, Islamic law occupies a central position as a source of legitimacy for political realities. On the other hand, the state has a major role in enforcing Islamic law correctly and appropriately. Third, the secularistic paradigm. This paradigm views the relationship between religion and the state as diametrically dichotomized. This paradigm rejects state law based on Islamic law, even rejects Islamic determination towards certain forms of state. Thus, Islamic law cannot simply be applied and enforced in a particular country. Islamic law cannot be used as positive state law unless it has been accepted by the state as national law. ${ }^{50}$

in fiqh as a product of ijtihad. Ujang Ruhyat Syamsoni, "Taqnin Al-Ahkam (Legislasi Hukum Islam Ke Dalam Hukum Nasional)," Nur El-Islam 2, no. 2 (2015): 168-93, https://ejurnal.iaiyasnibungo.ac.id/index.php/nurelislam/article/view/28.

${ }^{49}$ Rahmatunnair Rahmatunnair, "Paradigma Formalisasi Hukum Islam Di Indonesia," AHKAM : Jurnal Ilmu Syariah 12, no. 1 (2012): 99-108, https://doi.org/10.15408/ajis.v12i1.984.

${ }^{50}$ Rahmatunnair. 
Rahmatunnair argues that the formalization of Islamic law should take the form of transformation and internalization of Islamic legal values into the national legal system. In this case, Islamic law is not only seen as a static norm that prioritizes certainty and order but is also a norm that must be able to dynamically think and manipulate people's political behavior in realizing their ideals. ${ }^{51}$ Here, there are two reasons, external and internal reasons. The external reason is the state constitution which provides opportunities for the application of Islamic law for Indonesian Muslims, as reflected in Pancasila (Five Pillars)and the 1945 Constitution of the Republic of Indonesia. While the internal reason is, Islamic law itself which has legal principles, can be applied and accepted by the community and provide justice. In addition, in terms of the means that provide opportunities for the formalizing Islamic law, no less important is the maqāsid syari'ah or the goal of Islamic law which is aimed towards achieving happiness (benefits) and avoiding all forms of arbitrariness (harm). ${ }^{52}$

Based on the previous description, Islamic law as social engineering is an attempt to re-establish justice by applying Islamic law in regulations or legislation in the state. In addition, Islamic law must be able to adapt by continuing to make various approaches with other sciences to produce a social reflection. In this position, it makes Islamic law ease in accelerating the society, which is hope, as an effort to obtain justice through social engineering.

To achieve justice, there are two important considerations. The first is the source. And, second is the formulation of justice itself. The sources of the Islamic law that come from God's revelation, must answer the social challenges which in general always move dynamically following the development of the social culture of society. Here is the urgency of the role of the fuqaha, ulama, and other Muslim scholars to implement and develop Islamic law. Therefore, according to Fathurrahman Azhari, Islamic law, as part of the product of classical ulama thought in the context of social engineering, is understood by not being absolute or accepting the change. So, the things that are no longer in accordance with contemporary times need to be reviewed. ${ }^{53}$ In the aspect of the formulation of justice, Islamic law must be formulated in law or guidance in seeking

\footnotetext{
${ }^{51}$ Rahmatunnair.

${ }^{52}$ Rahmatunnair.

53 Fathurrahman Azhari, "Dinamika Perubahan Sosial Dan Hukum Islam," Al-Tahrir: Jurnal Pemikiran Islam 16, no. 1 (June 24, 2016): 197-221, https://doi.org/10.21154/al-tahrir.v16i1.322.
} 
justice. The reason is to achieve a universal law by achieving justice for humans and justice in the sight of God. ${ }^{54}$

A law of a realization of positive of Islamic $\operatorname{law}^{55}$ and has a function as a means of social engineering is Law Number 1 of 1974 concerning Marriage. Historically, this law was born from a hope from the government to make an Indonesian family with a national personality and a modern perspective. In addition, the Marriage Law is expected to regulate the creation of a future Indonesian family that is compatible with modern industrial society. ${ }^{56}$

One of the articles that show the social reconstruction efforts in the Act is related to marriage registration. In the explanation of the Marriage Law in the section on the principles of marriage in Indonesia, it states that the registration of each marriage is the same as important events in a person's life, for example, births or deaths which are stated in certificates, an official certificate which is also contained in the marriage registration. This shows that the state with its power is trying to perform social engineering by adding marriage requirements beyond the conditions in the fiqh book. In this case, the state conducts a marriage registration as a form of protection for all its citizens in guaranteeing the rights and obligations of each family member. ${ }^{57}$ And, the marriage law for Muslims that has been applied following the fiqh, since hundreds of years ago until now, does not contain the condition of marriage registration. For every Muslim, as long as the marriage is following the pillars and conditions outlined in the books of fiqh, then, the marriage is valid. Article 2 paragraph 1 of the Law accommodates the things that have been implemented by Indonesian Muslims. However, article 2 paragraph 2 which requires the registration of marriages shows that

\footnotetext{
54 Abdul Ghofur Anshori, Filsafat Hukum, Sejarah Aliran Dan Pemikiran (Yogyakarta: Gajah Mada University Press, 2005).

${ }^{55}$ The figure who clearly states that act No 1 of 1974 is a product of ijtihād is Prof. Dr. Hazairin, S.H. in a discussion section about the relationship between Islamic Marriage law and this particular marriage law. There are two arguments. The first argument is stated by Hazairin. The second argument is argued by Prof. Dr. J. Prins that has contradicted with the argument of Prof. Dr. Hazairin, S.H. But, M. Tahir Azhary approved the arguments that act No 1 of 1974 on marriage law is a product of ijtihäd. Danu Aris Setiyanto, "Hukum Islam Sebagai Rekayasa Sosial Dan Implikasinya Dalam Undang-Undang Perkawinan Di Indonesia," Ijtihad: Jurnal Wacana Hukum Islam Dan Kemanusiaan 17, no. 2 (2018): 175, https://doi.org/10.18326/ijtihad.v17i2.175-189.

56 Setiyanto.

${ }^{57}$ Setiyanto.
}

https://e-journal.iain-palangkaraya.ac.id/index.php/maslahah/index 
there is an effort by the government to add administrative requirements as a form of legal certainty and protection for its citizens.

Islamic law as a means of social reconstruction can also enter the public law, namely by making it as a review by the government to explore the sources of power to be used by using Islamic law as a mechanism. Corruption in Indonesia is very severe, and, it has become a culture. But, the punishment punished for the corruptors in Indonesia is still very light. The government, as a policymaker as well as a supervisory and regulatory apparatus for a legal product, must make a policy or legislation to be social engineering for all people in Indonesia.

Efforts need to consider by the government. For example, the law needs to consider the sources of law that live in society, such as Islamic law. It must be realized, that corruption is a form of extraordinary crime, just like terrorism and drugs. In Islamic law, criminal acts of corruption can be imposed with the type of $t a^{\prime} z i r$ punishment with the heaviest punishment of a death sentence to a light one, such as imprisonment, according to the severity of the act and the impact of corruption committed. ${ }^{58}$ The views of Muslim scholars and intellectuals can be applied in the laws and regulations in Indonesia so that the giving of sanctions for criminal acts of corruption for those who commit criminal acts of corruption repeatedly (recidivists) can be sentenced to a maximum penalty of death. Also, the crime of corporation corruption (jointly) for those who are proven to have committed an evil conspiracy by jointly causing losses to the State, could be given severe punishment, even the death penalty following the Qur'an, hadith, 'Ijma, and fatwa from fiqiyah scholars. ${ }^{59}$

\section{Conclusion}

Islamic law in Indonesia is part of the living law in the Indonesian Muslim community. Moreover, the existence of it is recognized as one of the sources of national law, besides Western law and customary law. This opens the opportunity to make Islamic law act as a means of social reconstruction, namely to create a better social condition. To make Islamic law a means of social reconstruction, the formalization of

${ }^{58}$ Bambang Widjoyanto, Abdul Malik Gismar, and Laode M. Syarif, Koruptor Itu Kafir: Telaah Fiqh Konsepsi Dalam Muhammadiyah Dan Nahdlatul Ulama (Bandung: Mizan, n.d.).

${ }^{59}$ Martha Safira, "Law as a Tool of Social Engineering Dalam Penanganan Tindak Pidana Korupsi Di Indonesia Ditinjau Dari Hukum Islam Dan Perundang-Undangan Di Indonesia," Kodifikasia 11, no. 1 (2017): 118-33, https://doi.org/10.2991/icsse-17.2018.28. 
Islamic law is inevitable. However, the formalization must be in the form of transformation and internalization of the values contained in Islamic law into the national law. In this case, Islamic law is not a static norm but must be understood as a norm that can dynamize thought and engineer the people's political behavior in realizing their ideals.

\section{BIBLIOGRAPHY}

Ahmad, Sabarudin, Novita Anggraeni, and Andrian Kukuh Pambudi. "A. Djazuli's Thinking Regarding Hifzu Al-Ummah: Dismissing the Entangled Bureaucracy to Commemorate the Era of Society 5.0." Journal de Jure 12, no. 1 (2020): 86-101. https://doi.org/10.18860/j-fsh.v12i1.8700.

Al-Amruzi, M. Fahmi. Harta Kekayaan Perkawinan Studi Komparatif Fiqh, KHI, Hukum Adat Dan KUHPerdata. Yogyakarta: Aswaja Pressindo, 2013.

Ali, Mohammad Daud. "Kedudukan Hukum Islam Dalam Sistem Hukum Indonesia." IJurnal Hukum \& Pembangunan 15 (1985): 14-32. http://jhp.ui.ac.id/index.php/home/article/view/1178.

Amin, Ma'ruf. Fatwa Dalam Sistem Hukum Islam. Jakarta: eLSAS, 2011.

Anshori, Abdul Ghofur. Filsafat Hukum, Sejarah Aliran Dan Pemikiran. Yogyakarta: Gajah Mada University Press, 2005.

Ash-Shiddieqy, M. Hasbi. Filsafat Hukum Islam. Jakarta: Bulan Bintang, 1975.

Atmajaya, A.P. Edi. "Hukum Sebagai Sarana Rekayasa Sosial." Opini Radar Lampung, 2012. https://issuu.com/ayep2/docs/300512/6.

Azhari, Fathurrahman. "Dinamika Perubahan Sosial Dan Hukum Islam." Al-Tahrir: Jurnal Pemikiran Islam 16, no. 1 (June 24, 2016): 197-221. https://doi.org/10.21154/al-tahrir.v16i1.322.

Azizi, A. Qadri. Eklektisme Hukum Nasional: Kompetisi Antara Hukum Islam Dan Hukum Umum. Yogyakarta: Gema Media, 2002.

Basri, Rusdaya. "Ibnu Qayyim Al-Jawziyyah Tentang Pengaruh Perubahan Sosial.” AlManahij: Jurnal Kajian Hukum Islam, 2015. https://doi.org/10.24090/mnh.v9i2.489.

Darmodiharjo, Dardi. Pokok-Pokok Filsafat Hukum: Apa Dan Bagaimana Filsafat Hukum Indonesia. Jakarta: Gramedia Pustaka Utama, 1996.

Hasan, Ahmadi. Adat Badamai. Banjarmasin: Antasari Press, 2007.

Hujbers, Theo. Filsafat Hukum Dalam Lintasan Sejarah. Yogyakarta: Kanisius, 1982.

Ishaq. Dasar-Dasar Ilmu Hukum. Jakarta: Sinar Grafika, 2018.

Izomiddin. Pemikiran Dan Filsafat Hukum Islam. Jakarta: Prenamedia Group, 2018.

Kosasih, Johannes Ibrahim, and Yohanes Hermanto Sirait. "Konsepsi Law As A Tool Of SOcial Engineering Sebagai Upaya Manajemen Hukum Dalam Menciptakan Kepastian Hukum." In Konferensi Nasional Optimalisasi COmminity Well-Being 
Dalam Perspektif Multidisipliner, 45-46. Bandung: Fakultas Psikologi Universitas Kristen Maranatha, 2015.

Koto, Alaudin. Filsafat Hukum Islam. Jakarta: RajaGrafindo Persada, 2014.

Kusumaatmadja, Mochtar. Konsep-Konsep Hukum Dalam Pembangunan. Bandung: Alumni, 2002.

Manan, Abdul. Aspek-Aspek Pengubah Hukum. Jakarta: Prenamedia Group, 2018.

Mas, Marwan. Pengantar Ilmu Hukum. Bogor: Ghalia Indonesia, 2015.

Muslim, Haris. "Pemikiran Ibnu Qayyim Al-Jauziyah (W 751 H/1350 M) Tentang Perubahan Fatwa Dan Relevansinya Dengan Penerapan Hukum Islam Di Indonesia." Al-Mashlahah Jurnal Hukum Islam Dan Pranata Sosial Islam 8, no. 2 (2020): 285-313. http://jurnal.staialhidayahbogor.ac.id/index.php/am/article/view/809.

Pelu, Ibnu Elmi A.S. "Kedudukan Fatwa DAlam Konstruksi Hukum Islam.” ElMashlahah 9, no. 2 (2019): 167-81. http://e-journal.iainpalangkaraya.ac.id/index.php/maslahah/article/view/1294.

PUTRI, DAR NELA. "Konsep Urf Sebagai Sumber Hukum Dalam Islam." El-

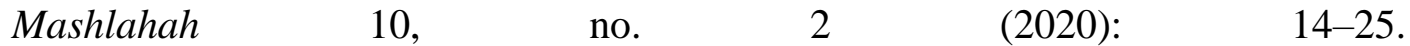
https://doi.org/10.23971/maslahah.v10i2.1911.

Raharjo, Satjipto. Ilmu Hukum. Bandung: Alumni, 1986.

Rahmatunnair, Rahmatunnair. "Paradigma Formalisasi Hukum Islam Di Indonesia." AHKAM: Jurnal Ilmu Syariah 12, no. 1 (2012): 99-108. https://doi.org/10.15408/ajis.v12i1.984.

Rahmawati. "Paradigma Perubahan Hukum Islam (Eksplorasi Pemikiran Ibnu Qayyim Al-Jauziyah)." Al-Bayyinah 1, no. 2 (2017): 17-28. https://doi.org/https://doi.org/10.35673/al-bayyinah.v1i2.14.

Rasyidi, Lili. Filsafat Hukum. Bandung: Remaja Rosdakarya, 1988.

Rasyidi, Lili, and Rasyidi Ira. Dasar-Dasar Filsafat Hukum. Bandung: Citra Aditya, 1990.

Ridwan, Ahmad Hasan, and Irfan Safruddin. Dasar-Dasar Epistemologi Islam. Bandung: Pustaka Setia, 2011.

Safira, Martha. "Law as a Tool of Social Engineering Dalam Penanganan Tindak Pidana Korupsi Di Indonesia Ditinjau Dari Hukum Islam Dan Perundang-Undangan Di Indonesia." Kodifikasia 11, no. 1 (2017): 118-33. https://doi.org/10.2991/icsse17.2018.28.

Salam, Samsir. "Hukum Dan Perubahan Sosial (Kajian Sosiologi Hukum)." Tahkim: Jurnal Hukum Dan Syariah 11, no. 1 (2015): 107-15. https://jurnal.iainambon.ac.id/index.php/THK/article/view/12.

Sarpini. “Prosedur Menyelesaikan Kasus Hukum Dengan Ijma'.” El-Mashlahah 9, no. 1 (2019): 16-28. https://doi.org/https://doi.org/10.23971/el-mas.v9i1.1256.

Setiyanto, Danu Aris. "Hukum Islam Sebagai Rekayasa Sosial Dan Implikasinya Dalam 
Undang-Undang Perkawinan Di Indonesia." Ijtihad: Jurnal Wacana Hukum Islam $\begin{array}{llllll}\text { Dan Kemanusiaan } & 17, \quad \text { no. } & 2 & \text { (2018): } & 175 .\end{array}$ https://doi.org/10.18326/ijtihad.v17i2.175-189.

Sibuea, Hotma P, and Waty Suwarty Haryono. "Pengaruh Mazhab Hukum Sosiological Jurisprudence Terhadap Perkembangan Pembangunan Hukum Di Indonesia Pada Masa Orde Baru." Jurnal Filsafat Hukum 1, no. 1 (2015): 103-11. http://journal.uta45jakarta.ac.id/index.php/JFH/article/view/1480.

Soekanto, Soerjono. Pemikiran Sosiologi Terhadap Hukum. Jakarta: Bina Aksara, 1998.

Syamsoni, Ujang Ruhyat. "Taqnin Al-Ahkam (Legislasi Hukum Islam Ke Dalam Hukum Nasional)." Nur El-Islam 2, no. 2 (2015): 168-93. https://ejurnal.iaiyasnibungo.ac.id/index.php/nurelislam/article/view/28.

Syarif, Mujar Ibnu. Ide Taqnin Ibn Al-Muqaffa Dan Relevansinya Dengan Penerapan Syariat Islam Di Indonesia. Jakarta: Renaisan dan Formasi, 2005.

Syarifuddin, Amir. Pembaharuan Pemikiran Dalam Hukum Islam. Padang: Angkasa Raya, 1993.

Thahir, A. Halil. Ijtihad Maqashid: Rekonstruksi Hukum Islam Berbasis Interkoneksitas Maslahah. Yogyakarta: LKiS Pelangi Aksara, 2015.

Widjoyanto, Bambang, Abdul Malik Gismar, and Laode M. Syarif. Koruptor Itu Kafir: Telaah Fiqh Konsepsi Dalam Muhammadiyah Dan Nahdlatul Ulama. Bandung: Mizan, n.d.

Wigisoebroto, Soetandyo. Dari Hukum Kolonial Ke Hukum Nasional: Dinamika Sosial Politik Dan Perkembangan Hukum Di Indonesia. Jakarta: Rajawali Press, 1994.

Yusdani. Mепији Hukum Keluarga Progresif. Jakarta: Kaukaba, 2015. 